\title{
Resveratrol Regulates Pathologic Angiogenesis by a Eukaryotic Elongation Factor-2 Kinase-Regulated Pathway
}

Aslam A. Khan, ${ }^{*}$ Dru S. Dace, ${ }^{*}$ Alexey G. Ryazanov, ${ }^{\dagger}$ Jennifer Kelly, ${ }^{*}$ and Rajendra S. Apte*

From the Departments of Ophthalmology and Visual Sciences, ${ }^{*}$ and Developmental Biology, ${ }^{\ddagger}$ Washington University School of Medicine, St. Louis, Missouri; and the Department of Pharmacology, ${ }^{\dagger}$ University of Dentistry and Medicine of New Jersey, R. W. Johnson Medical School, Piscataway, New Jersey

\begin{abstract}
Abnormal angiogenesis is central to the pathophysiology of diverse disease processes including cancers, ischemic and atherosclerotic heart disease, and visually debilitating eye disease. Resveratrol is a naturally occurring phytoalexin that has been demonstrated to ameliorate and decelerate the aging process as well as blunt end organ damage from obesity. These effects of resveratrol are largely mediated by members of the sirtuin family of proteins. We demonstrate that resveratrol can inhibit pathological angiogenesis in vivo and in vitro by a sirtuin-independent pathway. Resveratrol inhibits the proliferation and migration of vascular endothelial cells by activating eukaryotic elongation factor- 2 kinase. The active kinase in turn phosphorylates and inactivates elongation factor-2, a key mediator of ribosomal transfer and protein translation. Functional inhibition of the kinase by gene deletion in vivo or RNA as well as pharmacological inhibition in vitro is able to completely reverse the effects of resveratrol on blood vessel growth. These studies have identified a novel and critical pathway that promotes aberrant vascular proliferation and one that is amenable to modulation by pharmacological means. In addition, these results have uncovered a sirtuin-independent pathway by which resveratrol regulates angiogenesis. (Am J Pathol 2010, 177:481-492; DOI: 10.2353/ajpath.2010.090836)
\end{abstract}

Resveratrol ( $3,4^{\prime}, 5$-trihydroxy-trans-stilbène) is a natural phytoalexin found in grapes, red more than white, and a variety of natural plants. It is reported to have specific protective effects against tumors and in Alzheimer disease while also having significant beneficial effects on overall health. ${ }^{1-4}$ In mice fed high-fat diets, resveratrol has been shown to protect organs from obesity-associated damage and increase life span. ${ }^{1}$ Mice fed resveratrol also demonstrate decreased insulin resistance, improved motor function, and elevated mitochondrial numbers. A carbohydrate-enriched diet has been shown to induce insulin resistance and hyperinsulinemia, which in turn is associated with elevated blood pressure and initiation of a complex biochemical cascade that leads to vascular cell damage. ${ }^{5,6}$ Oral administration of resveratrol was shown to inhibit insulin sensitivity and to reduce the body weight of mice fed on high-fat diet. ${ }^{7}$ Most of the effects of resveratrol on lifespan in lower life forms are thought to be mediated by the deacetylase sir-2, a member of the conserved sirtuin family of proteins. ${ }^{8}$ In mammals, there have been seven sirtuins described to date and the mammalian homolog of sir-2 is called Sirt1. Resveratrol is a potent activator of mammalian Sirt1, and most of the described effects of resveratrol in higher life forms on the regulation of glucose and insulin production and sensitivity, cell survival, fat metabolism, and effects of caloric restriction are thought to be mediated by Sirt1. ${ }^{1-4}$ Resveratrol also improves vascular endothelial and postischemic cardiac function in various experimen-

Supported by National Institutes of Health $(\mathrm{NIH})$ grant K08EY016139 (to R.S.A.), NIH Vision Core grant P30 EY 02687, Carl Marshall Reeves and Mildred Almen Reeves Foundation Inc. Award (to R.S.A.), Research to Prevent Blindness Inc. Career Development Award (to R.S.A.), International Retina Research Foundation (to R.S.A.), American Federation for Aging Research grant (to R.S.A.), American Retina Foundation (to R.S.A.), IRRF Callahan Award (to D.D. and A.A.K.), and a Research to Prevent Blindness Inc. Unrestricted grant.

Accepted for publication March 22, 2010.

CME Disclosure: None of the authors disclosed any relevant financial relationships.

Supplemental material for this article can be found on http://ajp. amjpathol.org.

Address reprint requests to Rajendra S. Apte, M.D., Ph.D., 660 South Euclid Avenue, Box 8096, St. Louis, MO 63110. E-mail: apte@vision. wustl.edu. 
tal models, such as myocardial infarction and diabetes, but the precise effects of resveratrol on postdevelopmental angiogenesis remain unknown. ${ }^{5,9-11}$ The effects of resveratrol on angiogenesis are complex as resveratrol has been shown to be proangiogenic in the ischemic myocardium but antiangiogenic in cancers. ${ }^{12,13}$ As resveratrol has been shown to decelerate the aging process and modulate vascular endothelial cell function in diverse angiogenic beds, we explored its potential in regulating pathological angiogenesis.

Aberrant or pathological angiogenesis is central to the pathophysiology of disease in several types of cancers, atheromatous heart disease, and in diseases of the eye. In the eye, abnormal angiogenesis leads to blindness and can affect either the retina, as seen in diabetic retinopathy (the leading cause of blindness in working adults), retinopathy of prematurity (the leading cause of blindness in premature infants), or the choroid, as characterized by choroidal neovascularization (CNV) in agerelated macular degeneration (AMD). We assessed the effects of resveratrol on angiogenesis in vivo and in vitro and analyzed the mechanism by which resveratrol regulates angiogenic behavior. The findings in this study have significant bearing on our understanding of vascular endothelial proliferation and abnormal angiogenesis in disease processes.

\section{Materials and Methods}

\section{Animals}

All work was performed in accordance with the Association for Research in Vision and Ophthalmology (ARVO) guidelines. Comprehensive protocols of animal care and experimental design outlined in this study are on file and have been approved by the Washington University Committee on the Humane Care of Laboratory Animals (CHCLA). All animal caretakers and laboratory personnel have appropriate approvals based on specific American Association for Laboratory Animal Care (AALAC)-approved training programs. The facilities are inspected at regular intervals by a local University Committee and by unannounced visits directed by the Federal Government.

C57BL6 mice were purchased from Jackson Laboratories (Bar Harbor, ME). eEF2k ${ }^{-1-}$ mice (C57BL6) have been previously characterized and were provided by Dr. Alexey G. Ryazanov of UMDNJ-Robert Wood Johnson Medical School, Piscataway NJ. ${ }^{14}$

\section{Cell Lines and Reagents}

Human microvascular endothelial cells (HMVECs) were purchased from Lonza (Walkersville, MD) and were maintained in EBM-2 medium fortified with growth factors. Resveratrol, antiphosphoserine, antiphosphothreonine, and antiphosphotyrosine were purchased from Sigma (St. Louis, $\mathrm{MO}$ ). PeEF-2 (phosphorylated eukaryotic elongation factor 2) and eEF2k were purchased from Cell Signaling Technology (Danvers, MA). eEF2, peEF2k, pAMPK (Thr
172), and AMPK antibodies were purchased from Santa Cruz Inc. (Santa Cruz, CA). Resveratrol, antiphosphoserine (anti-pSer), antithreonine (anti-Thr) antibodies, 1-Hexadecyl-2-methyl-3-(phenyl methyl) $-1 \mathrm{H}$-imidazolium iodide $(\mathrm{NH} 125, \mathrm{IC50}=60 \mathrm{nmol} / \mathrm{L})$, fluorescein-labeled dextran, Cystamine (Cys), and Phenyl acetic acid (PAA) were purchased from Sigma (St. Louis, MO). ${ }^{15,16}$ Sirt1 inhibitor III (IC50 = $98 \mathrm{nmol} / \mathrm{L})$ was purchased from Calbiochem (Gibbstown, NJ). Streptavidin beads and BCA protein estimation kit was purchased from Pierce Biotech (Rockford, IL), and Streptavidin POD was purchased from Roche (Hague, IN). Tritiated $\left({ }^{3} \mathrm{H}\right)$ thymidine (TRA61) was purchased from GE Health Care (Piscataway, NJ). Fixative for the eyes was purchased from Biomeda (Foster City, CA). Alzet pumps were purchased from Direct Corporation (Cupertino, CA). Nitrocellulose membranes were purchased from Invitrogen (Carlsbad, CA). AMPK inhibitor BML275 (Ki = $109 \mathrm{nmol} / \mathrm{L})$ was purchased from Biomol (Plymouth, CA). ${ }^{17}$

\section{Treatment of Laser-Induced CNV in Mice}

Slow release osmotic Alzet pumps were loaded with either i) vehicle $(25 \% \mathrm{EtOH})$, ii) resveratrol (45), iii) Sirt1 inhibitor III (25 mg/kg) or NH125 (25 mg/kg) alone, or iv) resveratrol $(45 \mathrm{mg} / \mathrm{kg})$ + Sirt1 inhibitor III (25 mg/kg) or $\mathrm{NH} 125$ (25 mg/kg) and surgically placed subcutaneously on the flanks of mice 7 days before laser-induced injury (day -7 ) and treatment was continued for 7 days after laser. Rupture of the Bruch membrane with laser was used to initiate CNV in C57BL6 mice as described previously. ${ }^{18,19}$ Briefly, mice were anesthetized by injecting ketamine hydrochloride (100 mg/kg) and xylazine (13.4 $\mathrm{mg} / \mathrm{kg}$ ) intraperitoneally, and their pupils were dilated with $1 \%$ tropicamide and $2.5 \%$ phenylephrine. Using krypton red laser, four laser burns were placed around the optic nerve (0.05 seconds, $50 \mu \mathrm{m}$, and $110 \mathrm{~mW}$ ). Seven days after laser, mice were anesthetized as described above and perfused intraventricularly with fluorescein-labeled dextran. Mice were killed in a $\mathrm{CO}_{2}$ chamber, and their eyes were harvested for tissue processing. A dissecting microscope was used to remove the cornea and lens and to gently separate the retina from the underlying choroid and sclera. Micro scissors were used to make four radial incisions in the sclerochoroidal "eyecup" to prepare choroidal flat mounts on glass slides. The tissues were incubated in 4\% paraformaldehyde for 45 minutes and washed 3 times with $3 \%$ bovine serum albumin. A drop of fixative and a glass coverslip was placed on each slide. The choroidal flat mounts were analyzed for the presence of CNV by confocal microscopy. The extent of choroidal neovascularization was quantified by Metamorph Imaging software. We used $n \geq$ 5 mice for each group.

\section{Proliferation Assay}

HMVECs in log phase were cultured in 96-well flat bottom plates for adherence. Cells were then preincubated with either Sirt1 inhibitor III $(\text { IC50 }=98 \mathrm{nmol} / \mathrm{L})^{20}(25 \mathrm{nmol} / \mathrm{L}$, 
$50 \mathrm{nmol} / \mathrm{L}, 100 \mathrm{nmol} / \mathrm{L}$, and $200 \mathrm{nmol} / \mathrm{L}), \mathrm{NH} 125$ (IC50 = $95 \mathrm{nmol} / \mathrm{L})^{21}(50 \mathrm{nmol} / \mathrm{L}, 100 \mathrm{nmol} / \mathrm{L}$, and $200 \mathrm{nmol} / \mathrm{L})$, BML275 $(\mathrm{Ki}=109 \mathrm{nmol} / \mathrm{L})^{17}(100 \mathrm{nmol} / \mathrm{L})$, Cys $(1 \mathrm{mmol} /$ $\mathrm{L}),{ }^{15}$ or PAA $(5 \mathrm{mmol} / \mathrm{L})^{22}$ for 2 hours and then stimulated with resveratrol $(4 \mu \mathrm{g} / \mathrm{ml}=18 \mu \mathrm{M})$ for 8 hours. HMVECs were then incubated with ${ }^{3} \mathrm{H}$ thymidine $(40 \mu \mathrm{Ci} / \mathrm{ml})$ for an additional 12 hours. Plates were harvested and read using a Top count harvester and micro plate reader (Packard, Meriden, CT) to obtain counts. Resveratrol was dissolved in $0.2 \%$ of $\mathrm{EtOH}$ and used at concentrations ranging from $9 \mu \mathrm{mol} / \mathrm{L}$ to $154 \mu \mathrm{mol} / \mathrm{L}$ for in vitro assays.

\section{Scratch Assay}

The assay has been described previously. ${ }^{23}$ Briefly, HMVECs were cultured to confluence in six-well plates. Cells were then pretreated with or without Sirt1 inhibitor III $(50 \mathrm{nmol} / \mathrm{L}, 100 \mathrm{nmol} / \mathrm{L}$, and $200 \mathrm{nmol} / \mathrm{L})$ or $\mathrm{NH} 125$ (50 $\mathrm{nmol} / \mathrm{L}, 100 \mathrm{nmol} / \mathrm{L}$, and $200 \mathrm{nmol} / \mathrm{L})$ or PAA ( $5 \mathrm{mmol} / \mathrm{L})$ or Cys $(1 \mathrm{mmol} / \mathrm{L})$ or BML275 (100 nmol/L) for 2 hours, and a scratch was placed using a $200 \mu$ l pipette tip. HMVECs were then incubated for an additional 20 hours with or without added resveratrol (18 $\mu \mathrm{mol} / \mathrm{L})$, and images were taken at 0 hours and 20 hours of resveratrol treatment.

\section{Western Blot Analysis}

HMVECs were stimulated with resveratrol $(18 \mu \mathrm{l})$ for several time points ( 0 to 1 hour) or were pretreated with $\mathrm{NH} 125$ (50 nmol/L, $100 \mathrm{nmol} / \mathrm{L}$, and $200 \mathrm{nmol} / \mathrm{L})$ or BML275 (100 nmol/L). Cells were then lysed using Triton X-100 lysis buffer $(25 \mathrm{mmol} / \mathrm{L}$ Tris- $\mathrm{HCl}, \mathrm{pH} 7.5,150$ $\mathrm{mmol} / \mathrm{L} \mathrm{NaCl}$, and $1 \%$ triton $\mathrm{X}-100$ ). Proteins were measured by a BCA kit, and 20 to $30 \mu \mathrm{g} / \mathrm{lane}$ of proteins were electrophoretically separated on 10\% SDS-PAGE gels and then transferred onto nitrocellulose membranes. Membranes were either probed with pan antiphosphoserine, antiphosphothreonine, or antiphosphotyrosine antibodies or specific antibodies to $\beta$-Actin, peEF2 (Thr 56), eEF2, or eEF2k.eEF2k.

\section{Immunoprecipitation}

Cell lysates were incubated with isotype control antibody or with either anti-pSerine or anti-pThreonine and Streptavidin beads, respectively, overnight at $4^{\circ} \mathrm{C}$. Beads were then washed three times using lysis buffer at $5000 \mathrm{rpm}$ for 5 minutes each. Sample loading dye $(1 \times)$ was added to the beads, and the samples were heated for 20 minutes at $95^{\circ} \mathrm{C}$. Beads were then loaded on to $10 \%$ SDS-PAGE gels and proteins were transferred onto nitrocellulose membranes for Western blotting as described above.

\section{Mass Spectrometry for Protein Identification}

HMVECs were treated with resveratrol ( $18 \mu \mathrm{mol} / \mathrm{L})$ for 30 minutes. The cells were then lysed and lysates (300 $\mu \mathrm{g}$ to $500 \mu \mathrm{g} / \mathrm{sample}$ ) were immunoprecipitated with anti-pSer or anti-pThr antibodies overnight at $4{ }^{\circ} \mathrm{C}$. Immunoprecipitates were then electrophoretically resolved onto a $10 \%$ SDS PAGE gel, and the gel was stained with Brilliant Blue stain (Sigma). The gel was then treated with destaining solution (40\% methanol, $50 \%$ water, and $10 \%$ glacial acetic acid). Visible bands of 95 and $130 \mathrm{kDa}$ (p-Thr) proteins and $75 \mathrm{kDa}$ and $130 \mathrm{kDa}$ (p-Ser) proteins were excised and sent for mass spectrometric analysis to Dr. Ross Tomaino in the Taplin biological mass spectrometry laboratory at Harvard Medical School, Cambridge, MA.

\section{Sirt1 Activity Assay}

In vitro activity of Sirt1 was assessed according to the manufacturer's protocol (Biomol, Plymouth, PA). Briefly, assays were performed using Fluor de Lys-SIRT1, NAD ${ }^{+}$, and SIRT1, in the absence and presence of resveratrol in SIRT1 assay buffer (25 mmol/L Tris-Cl, pH 8.0, 137 $\mathrm{mmol} / \mathrm{L} \mathrm{NaCl}, 2.7 \mathrm{mmol} / \mathrm{L} \mathrm{KCl}, 1 \mathrm{mmol} / \mathrm{L} \mathrm{MgCl}, 1 \mathrm{mg} / \mathrm{ml}$ bovine serum albumin). The buffer, dimethyl sulfoxide, resveratrol, suramin, Sirt1 inh III (200 nmol/L), and SIRT1 were preincubated for 10 minutes. Reactions were initiated by the addition of $2 \times$ concentrations of the Fluor de Lys peptide and $\mathrm{NAD}^{+}$. Before quenching the reaction, 2 $\mathrm{mmol} / \mathrm{L}$ nicotinamide was added to $1 \times$ Developer II in the assay buffer $(25 \mathrm{mmol} / \mathrm{L}$ Tris, $\mathrm{pH} 8.0,137 \mathrm{mmol} / \mathrm{L} \mathrm{NaCl}$ $2.7 \mathrm{mmol} / \mathrm{L} \mathrm{KCl}, 1 \mathrm{mmol} / \mathrm{L} \mathrm{MgCl}_{2}$ ) as indicated in the BioMol product sheets. At each time point, $50 \mu \mathrm{l}$ of the reaction was removed and mixed with $50 \mu$ l of the developer solution. The quenched samples were kept at $37^{\circ} \mathrm{C}$ for 45 minutes before fluorescence reading. Fluorescence readings were obtained using the SpectraMax Gemini EM fluorometer (Molecular Devices, Sunnyvale$\mathrm{CA}$ ), with the excitation wavelength set to $360 \mathrm{~nm}$ and the emission set to $460 \mathrm{~nm}$ (according to Biomol specification). For sirt 1 activity in vivo, lysates from the eyes treated with i) Vehicle (25\% EtOH), ii) Resveratrol (45 mg/kg), iii) Sirt1 Inhibitor III (25 mg/kg), and iv) Sirt1 Inhibitor III + resveratrol were incubated with substrate (Fluor de LysSirt $1+N A D^{+}$) for 45 minutes. Samples were read by a micro plate-reading fluorometer at an excitation wavelength of $360 \mathrm{~nm}$ and emission wavelength of $460 \mathrm{~nm}^{3,24}$

\section{Matrigel Plug Assay}

Matrigel assay was performed as described previously. ${ }^{25}$ Briefly, C57BL6 Mice $(n=5)$ were treated with i) Vehicle (25\% EtOH), ii) Resveratrol (45 mg/kg), iii) NH125 (25 $\mathrm{mg} / \mathrm{kg}$ ), and iv) $\mathrm{NH} 125$ + Resveratrol using osmotic pumps 7 days before matrigel (BD Biosciences, San Jose, CA) injection. Matrigel (200 $\mu$ l/mouse) was injected subcutaneously. Treatment was continued for 7 more days. Mice were then killed, and matrigel plugs along with blood vessels were collected in PBS and incubated at $4^{\circ} \mathrm{C}$ for 24 hours. Matrigel plugs were vortexed and supernatants were analyzed for hemoglobin by using Quantichrome Hemoglobin assay kit (Bio Assay Systems, Hayward, CA). ${ }^{26}$ 


\section{siRNA Transfection}

Transfection was performed using manufacturer's protocol (Santa Cruz Biotech, Santa Cruz, CA). Healthy and subconfluent cells $\left(2 \times 10^{5}\right.$ cells per well) were cultured in six-well tissue culture plates and incubated at $37^{\circ} \mathrm{C}$ in a CO2 incubator until the cells were 60 to $80 \%$ confluent. Cell viability was confirmed one day before siRNA transfection.

Solution A: For each transfection, $6 \mu$ of siRNA duplex (i.e., $0.8 \mu \mathrm{g}$ or 60 pmols siRNA) was diluted in $100 \mu \mathrm{l}$ siRNA Transfection Medium: sc-36868.

Solution B: For each transfection, $6 \mu \mathrm{l}$ of siRNA transfection reagent (sc-29528) was diluted in $100 \mu \mathrm{l}$ siRNA Transfection Medium. siRNA duplex solution (Solution A) was directly added to the transfection reagent (Solution B) and mixed gently by pipetting the solution up and down and incubated the mixture for 30 minutes at room temperature. Cells were washed twice with $1 \mathrm{ml}$ of siRNA transfection medium. Transfection medium $(0.8 \mathrm{ml})$ was added to siRNA solutions (Solution $A$ and Solution B) for each transfection to each tube and mixed gently. SiRNA solution was overlaid over the cells, and cells were incubated at $37^{\circ} \mathrm{C}$ for 6 hours. One $\mathrm{ml}$ of fresh medium with $2 \times$ Fetal Calf Serum (FCS) was added to the cells with siRNA solution and incubated further for 18 to 20 hours. Medium was removed from the cells, fresh medium with $1 \times$ Fetal Calf Serum (FCS) was added to the cells, and cells were used for proliferation and migration. RT-PCR and Western blot analysis were used to confirm the down-regulation of gene and protein expression. Specificity of RNA inhibition was confirmed using control siRNA.

\section{Cell Cycle Analysis}

Cells were trypsinized and suspended in medium containing 10\% Fetal Calf Serum (FCS) and centrifuged (1000 rpm, 5 minutes). Pellets were then suspended in PBS $(1 \mathrm{ml})$. Cells were fixed by adding the cell suspension to $2.5 \mathrm{ml}$ absolute $\mathrm{EtOH}$ (final concentration approx. $70 \%$ ), vortexed at $500 \mathrm{rpm}$ while adding the $\mathrm{EtOH}$ to prevent clustering of cells during the fixation. Cells were incubated on ice for 15 minutes and then centrifuged at 1500 rpm for 5 minutes. Cells were suspended in $500 \mu \mathrm{l}$ propidium iodide solution ( $50 \mu \mathrm{g} / \mathrm{ml}, 0.05 \%$ Triton X-100, and $0.1 \mathrm{mg} / \mathrm{ml}$ RNase $A$ in PBS) and incubated for 40 minutes at $37^{\circ} \mathrm{C} .3 \mathrm{ml}$ of PBS was added to pellet the cells (1500 rpm, 5 minutes) and supernatants were discarded. Cells were then suspended in $500 \mu$ l PBS for flow cytometric analysis.

\section{Tube Formation Assay}

Tube assay was performed as previously described. ${ }^{18}$ Briefly, matrigel (100 $\mu$ l per well) was coated in a 96-well plate and the plate was incubated at $37^{\circ} \mathrm{C}$ for 30 minutes. Cells were plated at 15,000 cells per well density and then cultured in medium with or without resveratrol (18 $\mu \mathrm{mol} / \mathrm{L})$ for 20 hours. Photographs were then taken at 1 hour and 20 hours for analysis of tube formation.

\section{Statistical Analysis}

Student $t$ test (Sigmaplot) was used for statistical analysis of results. A $P$ value $<0.05$ was recorded as significant.

\section{Results}

Resveratrol Inhibits Injury-Induced Angiogenesis by a SIRT1-Independent Pathway

Laser injury-induced CNV has been used as a murine surrogate for studying abnormal angiogenesis in the eye as seen in AMD. ${ }^{18,19,27}$ Although an acute injury model for a chronic disease process, it is well characterized and has been highly predictive of agents that have since been proven to be efficacious in treatment. ${ }^{28}$ To test the effect of resveratrol on injury-induced angiogenesis in the eye, mice were treated with i) vehicle $(25 \% \mathrm{EtOH})$, ii) resveratrol (22.5 mg/kg), or iii) resveratrol (45 mg/kg) 7 days before and after the laser-induced injury. We observed a significant $(P=0.034)$ reduction in CNV at higher dose of resveratrol treatment $(45 \mathrm{mg} / \mathrm{kg}$ ), suggesting a protective role for resveratrol against the development and/or sustenance of CNV (Figure 1, A and B). Earlier studies dissolved resveratrol in drinking water and used higher doses in the range of $100 \mathrm{mg} / \mathrm{kg}$ to 400 $\mathrm{mg} / \mathrm{kg}$. We chose to use lower doses as we used subcutaneous osmotic pumps with higher and more sustained drug availability in our study. Given the importance of sirtuins in mediating the effects of resveratrol, it is interesting that Sirt1 has been shown to regulate vascular endothelial sprouting in vitro. ${ }^{29}$ We tested the ability of Sirt1 inhibitor III, a specific inhibitor of Sirt1 activity, to reverse resveratrol-mediated inhibition of CNV. Sirt1 inhibitor III in molar excess $(25 \mathrm{mg} / \mathrm{kg}$ ) did not reverse the inhibitory effects of resveratrol on CNV (Figure 1, C and D). The ability of Sirt1 to inhibit Sirt1 activity in vitro and in vivo was assessed in the Sirt1 activity assay as described above. Sirt1 inh III inhibited Sirt1 activity in vitro $(P=1.3$ $\left.\mathrm{e}^{-3}\right)$ more efficiently than suramin $\left(P=4.5 \mathrm{e}^{-3}\right)$, a known inhibitor of Sirt1, confirming robust inhibition of Sirt1 activity with this inhibitor (see supplemental Figure S1 at http://ajp.amjpathol.org). For in vivo Sirt1 activity, C57BL6 mice were treated with i) vehicle $(25 \% \mathrm{EtOH})$, ii) resveratrol (45 mg/kg), iii) Sirt1 inh III (25 mg/kg), and iv) resveratrol + Sirt1 inh III for 7 days before laser injury. Mice were lasered at day 7 , and treatment was continued for 7 more days. Mice were then killed and eyes were collected and lysed. Sirt1 activity was measured in the lysates of these eyes. We found that Sirt1 inhibitor III significantly inhibited Sirt1 activity in vivo (see supplemental Figure S1B at http://ajp.amjpathol.org). These data suggest that the Sirt1 does not mediate the effects of resveratrol on CNV. 
A

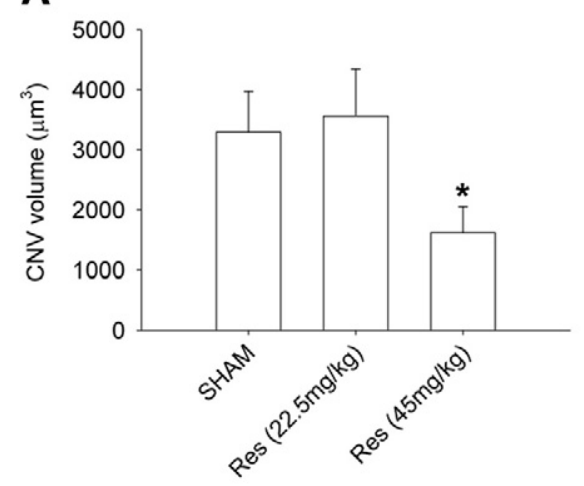

C

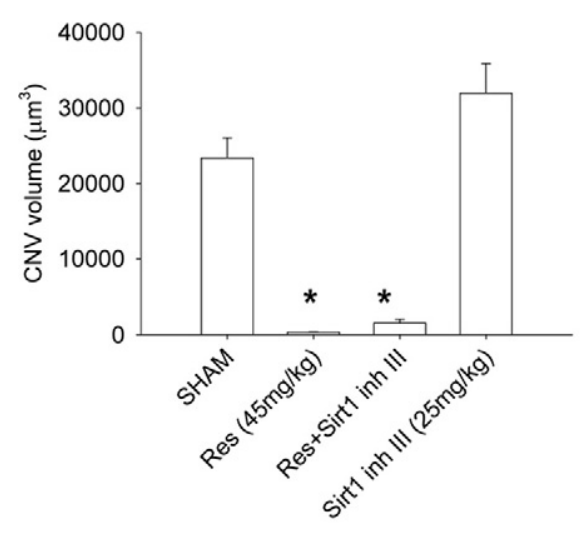

B SHAM

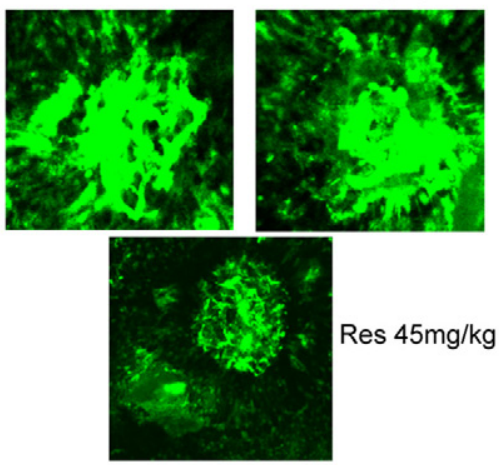

D
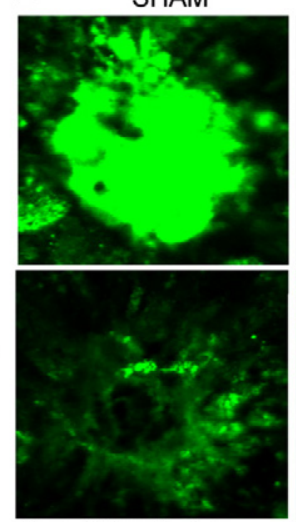

$\operatorname{Res}(45 \mathrm{mg} / \mathrm{kg})+$

Sirt1 Inh III $(25 \mathrm{mg} / \mathrm{kg})$
$\operatorname{Res}(45 \mathrm{mg} / \mathrm{kg})$

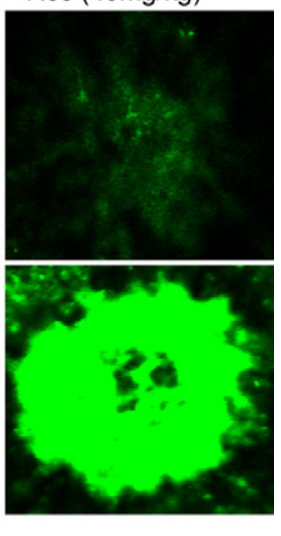

Sirt1 Inh III (25mg/kg)
Figure 1. Resveratrol inhibits $\mathrm{CNV}$ in mice in a Sirt1-independent manner. A: C57BL6 mice ( $n \geq$ 5 per group) were treated with sham (vehicle$25 \% \mathrm{EtOH}$ ) or resveratrol (Res- $22.5 \mathrm{mg} / \mathrm{kg}$ or 45 $\mathrm{mg} / \mathrm{kg}$ ) seven days before laser-induced injury, and treatment was continued for seven more days. CNV was quantified by confocal microscopy. B: Representative CNV lesions from shamor resveratrol-treated mice. C: C57BL6 mice ( $n=$ 5 per group) were treated with sham (vehicle), resveratrol ( $45 \mathrm{mg} / \mathrm{kg})$, Sirt1 Inh III $(25 \mathrm{mg} / \mathrm{kg})$, or resveratrol + Sirt1 Inh III for seven days before laser. Treatment was then continued for seven additional days after laser. CNV was quantified by confocal microscopy $\mathbf{D}$ : Representative $\mathrm{CNV}$ lesions from sham-treated, resveratroltreated, or sirt1 inh III + resveratrol-treated mice. $\mathrm{CNV}$ volumes are average values $\pm \mathrm{SE}$. ${ }^{*} P \leq 0.05$ by Student $t$ test.

\section{Resveratrol-Induced Endothelial Cell \\ Proliferation and Migration Is Independent of Sirt1 Activity}

Cell cycle plays an important role in the proliferation and migration of endothelial cells. We evaluated whether resveratrol had any effect on cell cycle in these cells. HMVECs were cultured with or without resveratrol $(4 \mu \mathrm{g} /$ $\mathrm{ml}$ ) for 20 hours, and cell cycle events were assessed by flow cytometry. We found that resveratrol arrested about $40 \%$ of HMVECs in S phase, suggesting that resveratrol might play a role in proliferation and migration of endothelial cells (Figure 2A). Proliferation and migration of vascular endothelial cells is a prerequisite for blood vessel formation. Therefore, we tested the effect of resveratrol on proliferation of HMVECs in a modified ${ }^{3} \mathrm{H}$ thymidine assay described above. HMVECs were treated with different doses of resveratrol (2 to $16 \mu \mathrm{g} / \mathrm{ml}$ ) for 8 hours, and proliferation was assessed by the ability of these cells to incorporate ${ }^{3} \mathrm{H}$ thymidine $(40 \mu \mathrm{Ci} / \mathrm{ml})$. We observed a dose-dependent inhibition of HMVEC proliferation, and 4 $\mu \mathrm{g} / \mathrm{ml}$ was found to be the optimal dose (Figure 2B). To determine whether sirt1 was involved in the ability of resveratrol to inhibit proliferation of endothelial cells, HMVECs were treated with i) medium, ii) resveratrol (4 $\mu \mathrm{g} / \mathrm{ml}$ ) only, iii) Sirt1 inhibitor III (200 nmol/L) only, or iv) resveratrol $(4 \mu \mathrm{g} / \mathrm{ml})+$ Sirt1 inhibitor III (25 to $200 \mathrm{nmol} / \mathrm{L})$ (pretreatment with Sirt1 inhibitor III for 2 hours before adding resveratrol). Cell proliferation was assessed by the ability to incorporate ${ }^{3} \mathrm{H}$ thymidine $(40 \mu \mathrm{Ci} / \mathrm{ml})$. Treatment with resveratrol significantly inhibited $(P<0.001)$ proliferation of HMVECs, and Sirt1 inhibitor III (25 to 200 $\mathrm{nmol} / \mathrm{L})$ did not reverse the effect of resveratrol $(P<$ 0.001). Moreover, Sirt1 inhibitor III alone did not have any effect ( $P=0.2559$ ) on HMVEC proliferation, confirming that the effect was independent of Sirt1 (Figure $2 \mathrm{C}$ ). We also tested the ability of resveratrol to inhibit the migration of HMVECs in a scratch assay. ${ }^{23}$ HMVECs were treated with i) medium only or ii) pretreated with Sirt1 inhibitor III $(200 \mathrm{nmol} / \mathrm{L})$ for 2 hours and then treated with resveratrol (4 $\mu \mathrm{g} / \mathrm{ml})$ for 20 hours. Resveratrol significantly inhibited the ability of HMVECs to fill the gap $(P<0.001)$ (i.e., migrate into the scratched area as compared with untreated cells which completely filled the gap by the 20 hours time point). Sirt1 inhibitor III did not affect the ability of resveratrol to inhibit migration of HMVECs $(P<0.001)$, confirming that the effect of resveratrol on vascular endothelial cell migration was Sirt1-independent (Figure 2D). To definitively prove that the effects of resveratrol are indeed Sirt1-independent, we knocked down Sirt1 expression in HMVECs using inhibitory RNA. Inhibition of Sirt1 expression by RNA inhibition did not reverse the effects of resveratrol on the proliferation or migration of HMVECS (Figure 2, E and F, and see supplemental Figure S2D at http://ajp.amjpathol.org). 
A

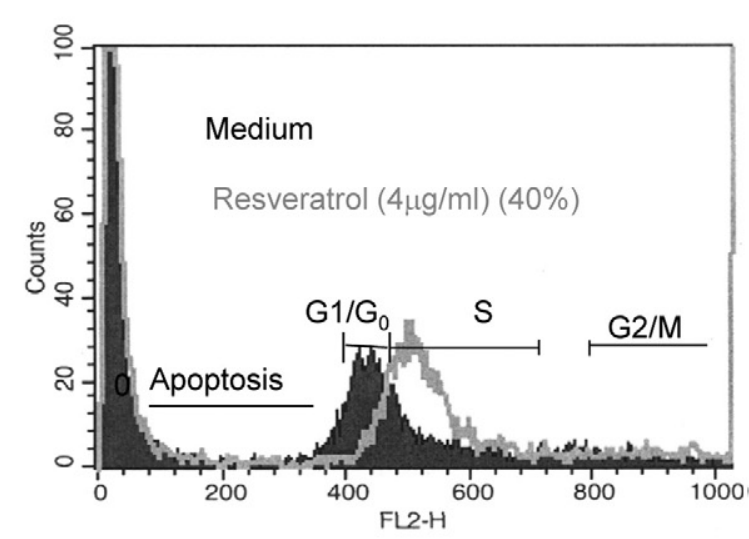

D

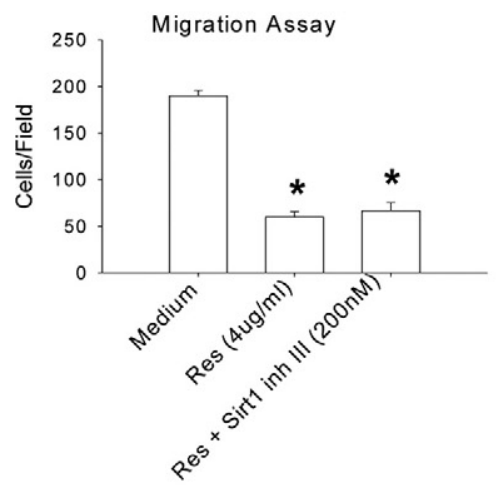

B

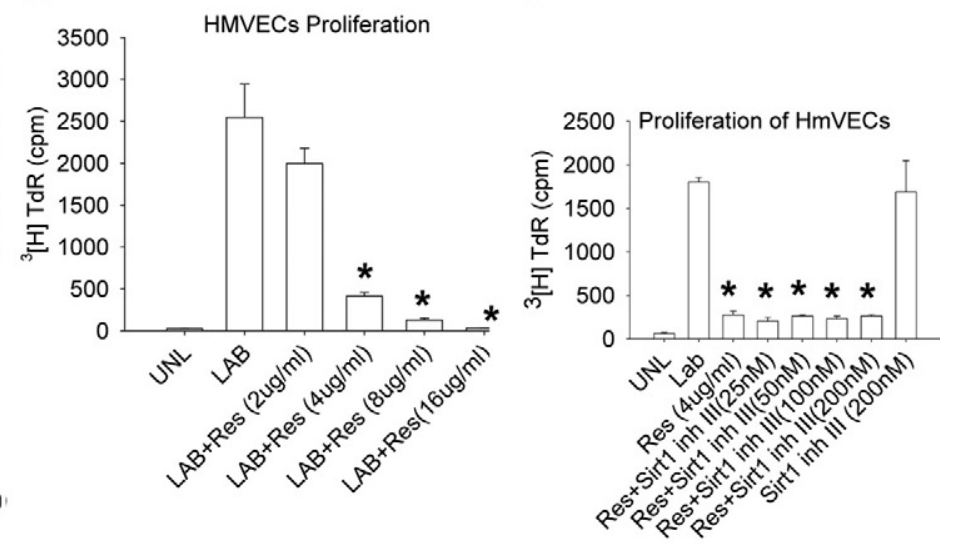

Figure 2. Resveratrol inhibits proliferation and migration of HMVECs in a Sirt1-independent manner. A: Cell cycle analysis: HMVECs were treated with resveratrol $(4 \mu \mathrm{g} / \mathrm{ml})$ then stained with propidium iodide and analyzed by FACS (Flow Cytometry). B: HMVECs were treated with resveratrol ( 2 to $16 \mu \mathrm{g} / \mathrm{ml})$, and cell proliferation was assayed. C: Proliferation assay: HMVECs were pretreated with Sirt1 inh III ( 25 to 200 nmol/L) for two hours, and then the cells were treated with resveratrol $(4 \mu \mathrm{g} / \mathrm{ml})$ for eight hours. Cell proliferation was quantified by measuring incorporation of ${ }^{3} \mathrm{H}$ thymidine ( $\left.40 \mu \mathrm{Ci} / \mathrm{ml}\right)$. D: $\mathrm{HMVECs}$ were cultured to confluence, and a scratch was placed in the center of the wells. Migration of cells into the gap was measured at 20 hours. E: HMVECs were transfected with Sirt1 siRNA or control siRNA ( 60 pmols) and then treated with resveratrol ( $4 \mu \mathrm{g} / \mathrm{ml})$ for eight hours. Cell proliferation was measured as described in the Materials and Methods. F: HMVECs were transfected with Sirt1 siRNA or control siRNA ( 60 pmols) and then treated with resveratrol (4 $\mu \mathrm{g} / \mathrm{ml})$. Migration of cells into the gap was measured in a scratch assay as described in the Materials and Methods. UNL indicates unlabeled cells; LAB, labeled. Values are averages \pm SE. ${ }^{*} P \leq 0.05$ by Student $t$ test.

\section{Resveratrol Induces Differential Phosphorylation of Serine and Threonine Residues but Not Tyrosine Residues in HMVECs}

We evaluated the effects of resveratrol on intracellular signaling pathways in HMVECs to determine key molecules that may be involved in inhibiting endothelial cell proliferation and migration. Intracellular phosphorylation events are critical, necessary, and ubiquitous mechanisms of cell activation. We assessed the serine, threonine, and tyrosine phosphorylation patterns within HMVECs and the effect of resveratrol on these events. To determine differential phosphorylation of serine, threonine, and tyrosine residues, HMVECs were treated with resveratrol $(4 \mu \mathrm{g} / \mathrm{ml})$ for several time points $(0,15,30$, or 60 minutes). Cells were lysed, and the lysates were evaluated for serine, threonine, and tyrosine phosphorylation by Western blotting. On resveratrol treatment, we observed prominent phosphorylation of serine residues of
$75 \mathrm{kDa}$ and $130 \mathrm{kDa}$ proteins, and threonine residues of $95 \mathrm{kDa}$ and $130 \mathrm{kDa}$ proteins (see supplemental Figure S3, A and B at http://ajp.amjpathol.org). There was no difference in tyrosine phosphorylation observed with immunoblotting with anti-ptyr antibodies before or after treatment of HMVECs with resveratrol (data not shown).

\section{Immunoprecipitation of HMVECs Lysates after Resveratrol Treatment and Mass Spectrometry Leads to Identification of Potential Target Proteins}

Resveratrol treatment of HMVECs leads to phosphorylation of serine and threonine residues of $75 \mathrm{kDa}$ and 130 $\mathrm{kDa}$; and $95 \mathrm{kDa}$ and $130 \mathrm{kDa}$ proteins, respectively. To determine the identity of these molecules, mass spectrometric analysis was performed. We could identify the following three unique proteins after mass spectro- 
metric analysis of the samples (see supplemental Table 1 at http://ajp.amjpathol.org): pyruvate carboxylase (PCB)-130 kDa-serine; tissue Transglutaminase II (TGM2)-77 kDa-serine; elongation Factor 2 (eEF2)-95 kDa-threonine.

\section{PCB and TGM2 Do Not Mediate Resveratrol-Induced Effects on Endothelial Cells}

While PCB is an enzyme involved in the TCA cycle and TGM2 regulates extracellular matrix and tissue protection, eEF2 plays a robust role in ribosomal translocation during protein translation and the growth and proliferation of diverse cell types. ${ }^{30-34}$ The dephosphorylated form of eEF2 is the active protein that gets inactivated on threonine phosphorylation. ${ }^{33}$ HMVECs were pretreated with 1 $\mathrm{mmol} / \mathrm{L}$ Cys, an inhibitor of TGM2, or $5 \mathrm{mmol} / \mathrm{L}$ PAA, a PCB inhibitor before resveratrol treatment and tested in the scratch and ${ }^{3} \mathrm{H}$ thymidine proliferation assays. PAA and Cys failed to neutralize the effect of resveratrol on migration or proliferation of HMVECs (see supplemental Figure S3, D-F at http://ajp.amjpathol.org). These results suggest that the effects of resveratrol on vascular endothelial cells are independent of PCB or TGM2.

\section{Inactivation of eEF2 by eEF2k is Responsible for Effects of Resveratrol on Endothelial Cells}

Threonine phosphorylation is a critical event in eEF2 function as threonine phosphorylation leads to inactivation of eEF2. ${ }^{33,34}$ Interestingly, resveratrol was shown to induce eEF2 phosphorylation in neonatal rat cardiac myocytes and inhibit their proliferation. ${ }^{5}$ eEF2k is a dedicated kinase that phosphorylates eEF2 at threonine and inactivates it, rendering it unable to catalyze ribosomal translocation. ${ }^{33,34}$ This regulation of eEF2 activity by its kinase is critical in modulating cell proliferation. Regulation of eEF2k in turn is highly complex because it can be phosphorylated on several serine residues. eEF2k phosphorylation at serine 366 is mediated by S6K 1 and RSKs (ribosomal S6 kinases) and leads to inhibition of its activity. ${ }^{35}$ Cdc2-cyclin B phosphorylates eEF2k at serine 359 and inhibits its activity. ${ }^{36}$ In contrast, phosphorylation of eEF2k at serine 398 by AMPK activates it. ${ }^{37}$ The serine 398 phosphorylated form of the kinase is the active form that catalyzes inactivation of eEF2. ${ }^{14,38}$ To directly assess the role of eEF2k inhibition on proliferation and migration of HMVECs, cells were either treated with i) medium, ii) resveratrol (4 $\mu \mathrm{g} / \mathrm{ml})$, iii) NH125 (200 nmol/L) alone, or iv) resveratrol $+\mathrm{NH} 125(100 \mathrm{nmol} / \mathrm{L}$ and $200 \mathrm{nmol} / \mathrm{L})$, a selective inhibitor of eEF2k function. ${ }^{21}$ Inhibition of eEF2k with $\mathrm{NH} 125$ completely neutralized $(P=0.18)$ the antiproliferative and antimigration effects of resveratrol treatment on HMVECs, suggesting the involvement of eEF2 and eEF2k in resveratrol-induced effects on endothelial cells (Figure $3, \mathrm{~A}-\mathrm{C}$ ). To prove conclusively that the resveratrol induced effects on HMVEC proliferation and migration are indeed mediated by eEF2 and eEF2k, we knocked down either eEF2 or eEF2k in HMVECs (see supplemental Figure S4, B-C at http://ajp.amjpathol.org). eEF2k knockdown by itself did not affect the migration potential of HMVECs but abrogated ability of resveratrol to inhibit eEF2 and HMVECs proliferation and migration. (Figure 3, D-E, see supplemental Figure S4A at $h t t p: / /$ ajp.amjpathol.org). On the other hand, eEF2 knockdown by itself inhibited the migration of HMVECs. We next examined the intracellular activation profiles of eEF2 and eEF2k after resveratrol treatment. HMVECs were stimulated with resveratrol $(4 \mu \mathrm{g} / \mathrm{ml})$ for various time points, after which cell lysates were prepared and immunoprecipitated with pan anti-pThr antibody and subsequently blotted with anti-eEF2 antibody. We observed a timedependent threonine phosphorylation of eEF2 after treatment with resveratrol (Figure 3F). This was confirmed by treating HMVECs with resveratrol $(4 \mu \mathrm{g} / \mathrm{ml})$ for several time points and evaluating threonine phosphorylation of eEF2 with a specific anti- peEF2Thr antibody at several time points. A time-dependent increase in threonine phosphorylation of eEF2 was observed (Figure 3G). Western blot analysis also showed increased serine 398 phosphorylation of eEF2k after resveratrol treatment (Figure $3 \mathrm{H}$ ), suggesting that resveratrol leads to activation of eEF2k. To further confirm eEF2k activation by resveratrol, HMVECs were incubated with or without NH125 (50 $\mathrm{nmol} / \mathrm{L}, 100 \mathrm{nmol} / \mathrm{L}$, and $200 \mathrm{nmol} / \mathrm{L}$ ), a specific eEF2k inhibitor for 2 hours before resveratrol treatment. Cells lysates were evaluated for eEF2 phosphorylation. We observed increased threonine phosphorylation of eEF2 after resveratrol treatment, which was inhibited by $\mathrm{NH} 125$ in a dose dependent manner (Figure 3I).

\section{Resveratrol-Induced Effects on eEF2 and eEF2 Kinase Activation Profiles are Mediated by AMPK}

Resveratrol has been shown to activate AMPK by phosphorylation at threonine $172 .{ }^{39}$ We were interested in testing whether resveratrol inactivates eEF2 via AMPK. To test this hypothesis, HMVECs were preincubated with a known AMPK inhibitor before resveratrol treatment. Cell lysates were then evaluated for eEF2 phosphorylation. We found dose-dependent inhibition of eEF2 (Thr) phosphorylation, suggesting that AMPK is likely to be involved in resveratrol-induced phosphorylation and deactivation of eEF2 (Figure 4A). We next determined the effect of AMPK on eEF2k activation and found that AMPK inhibitor BML275 reversed the eEF2k (ser 398) phosphorylation seen with resveratrol treatment (Figure 4B). Because AMPK appears to mediate the resveratrol-induced effects on eEF2 and its dedicated kinase, we also evaluated the effect of resveratrol on direct activation of AMPK. HMVECs were pretreated with medium or BML275 (100 $\mathrm{nmol} / \mathrm{L}$ ) for 2 hours and then treated with resveratrol (4 $\mu \mathrm{g} / \mathrm{ml}$ ) for 15 minutes. We found that resveratrol induced AMPK (Thr 172) phosphorylation in HMVECs and that BML275 completely reversed it (Figure 4C). AMPK inhibition also reversed the effect of resveratrol on proliferation and migration of HMVECs $(P<0.01)$ by BML275 (Figure 4, D-F). We further confirmed the role of AMPK in 
A

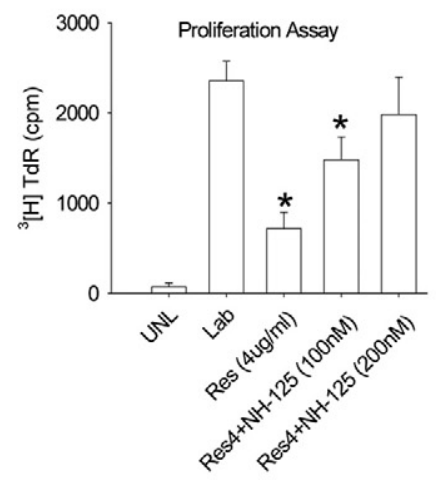

D
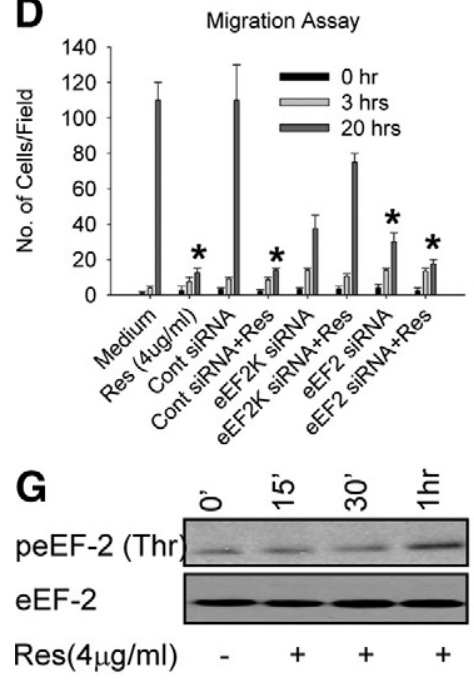

B

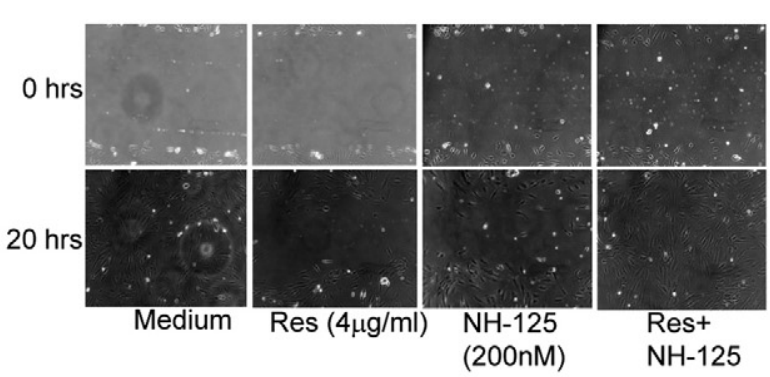

C

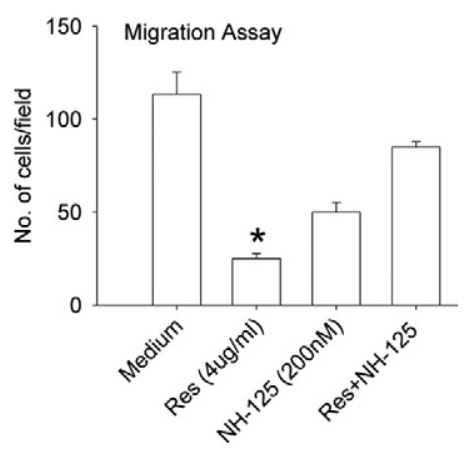

E

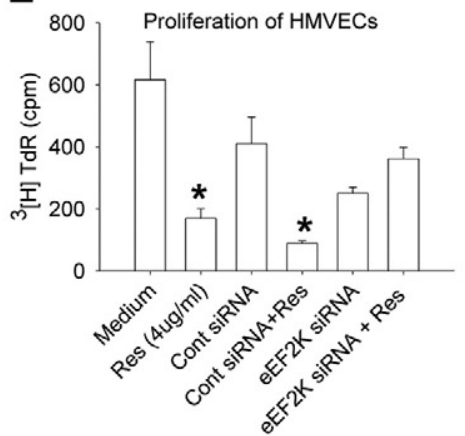

H peEF-2K (ser 398) eEF-2K

$\operatorname{Res}(4 \mu \mathrm{g} / \mathrm{ml})$

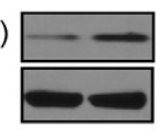

- +
$\mathbf{F}$

eEF-2 (WB)

Anti-pThr (pan)

(IP and WB)

$\operatorname{Res}(4 \mu \mathrm{g} / \mathrm{ml}) \quad-\quad+\quad++$

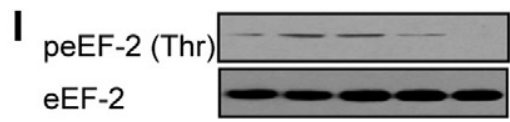

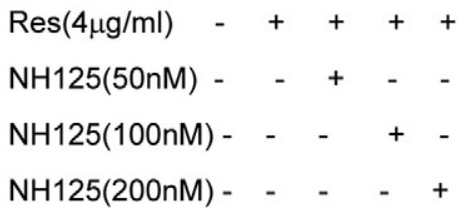

Figure 3. Resveratrol-induced effects on endothelial cell migration and proliferation are mediated by eEF2. A: HMVECs were pretreated with NH125 (100 nmol/L and $200 \mathrm{nmol} / \mathrm{L})$ for two hours and treated with resveratrol $(4 \mu \mathrm{g} / \mathrm{ml})$ for eight hours. ${ }^{3} \mathrm{H}$ Thymidine $(40 \mu \mathrm{Ci} / \mathrm{ml})$ was then added to the culture, and cell proliferation was measured after 12 hours. B: HMVECs were pretreated with NH125 (200 nmol/L) for two hours and treated with resveratrol ( $4 \mu \mathrm{g} / \mathrm{ml})$ for 20 hours. Cell proliferation was measured in the scratch assay. C: Cells were counted in four random fields in the scratch after 20 hours of incubation to quantify migration into the gap. D: HMVECs were transfected with eEF2 or eEF2K siRNA for 24 hours and treated with resveratrol ( $4 \mu \mathrm{g} / \mathrm{ml})$ for $20 \mathrm{hours}$. Cell migration was quantified at 20 hours in the scratch assay. E: HMVECs were transfected with eEF2 or eEF2K siRNA for 24 hours and treated with resveratrol ( $4 \mu \mathrm{g} / \mathrm{ml})$ for eight hours. ${ }^{3} \mathrm{H}$ Thymidine $(40 \mu \mathrm{Ci} / \mathrm{ml})$ was then added to the culture, and cell proliferation was measured after $12 \mathrm{hours}$. F: HMVECs were treated with resveratrol ( $4 \mu \mathrm{g} / \mathrm{ml}$ for 0, 15 minutes, 30 minutes, and 1 hour) and immunoprecipitated with anti-pan threonine after cell lysis [lower panel, Anti-pThr (pan)]. Immunoprecipitates were also analyzed for eEF2 by Western blotting (upper panel eEF2 WB). G: HMVECs were treated with resveratrol ( $4 \mu \mathrm{g} / \mathrm{ml}$ for $0,15 \mathrm{minutes}, 30 \mathrm{minutes}$, and 1 hour), cells were lysed, and lysates were evaluated for peEF2 (Thr) and eEF2. H: HMVECs were treated with resveratrol ( $4 \mu \mathrm{g} / \mathrm{ml}, 20 \mathrm{minutes}$ ), lysed, and analyzed for peEF2K (ser 398) and eEF2K by Western blotting. I: HMVECs were pretreated with NH125 (eEF2k inhibitor, $50 \mathrm{nmol} / \mathrm{L}$, 100 nmol/L, and 200 nmol/L) for two hours Cells were then treated with resveratrol $(4 \mu \mathrm{g} / \mathrm{ml})$ for 30 minutes and lysed. Lysates were evaluated for eEF2 and peEF2 (Thr) UNL stands for unlabeled cells and LAB stands for labeled cells. Values are averages \pm SE. ${ }^{*} P \leq 0.05$ by Student $t$ test.

resveratrol-induced effects on endothelial cell migration by RNA inhibition (Figure 4G, and see supplemental Figure S5 at http://ajp.amjpathol.org). These results confirmed that the effects of resveratrol on eEF2 and eEF2k are mediated by AMPK.

\section{eEF2 Kinase Inhibition Restores Angiogenesis in Vivo Within and Outside the Eye}

So far, we have shown that eEF2k-mediated inactivation of eEF2 is necessary and sufficient for the effects of resveratrol on HMVECs in vitro. We next investigated the in vivo phosphorylation of eEF2 and eEF2k in mice after treatment with resveratrol. C57BL6 mice were treated with i) vehicle (25\% EtOH), ii) resveratrol (45 mg/ $\mathrm{kg})$, iii) $\mathrm{NH} 125$ (25 mg/kg), and iv) resveratrol $+\mathrm{NH} 125$ for 7 days before laser injury using osmotic pumps, and the treatment was continued for 7 days after laser. Mice were killed, eyes were harvested, and the lysates were analyzed for eEF2 and eEF2k phosphorylation by Western blotting. We found that the eyes treated with resveratrol had increased eEF2 and eEF2k phosphorylation compared with sham or NH125-treated eyes (Figure 5, A and $\mathrm{B})$, confirming that resveratrol leads to the phosphorylation of eEF2 (Thr) and eEF2k (ser 398). In contrast, eyes from eEF2 $\mathrm{k}^{-1-}$ mice treated with resveratrol $(45 \mathrm{mg} / \mathrm{kg}$ ) did not demonstrate an increase in phosphorylation of eEF2 (Thr) (Figure 5C). We further investigated the effects of inhibiting eEF2k activity with $\mathrm{NH} 125$ on CNV in vivo. Mice were treated with i) vehicle $(25 \% \mathrm{EtOH}$, ii) resveratrol (45 mg/kg), iii) $\mathrm{NH} 125$ (25 mg/kg), and iv) $\mathrm{NH} 125$ + Resveratrol using 14-day osmotic pumps 
A
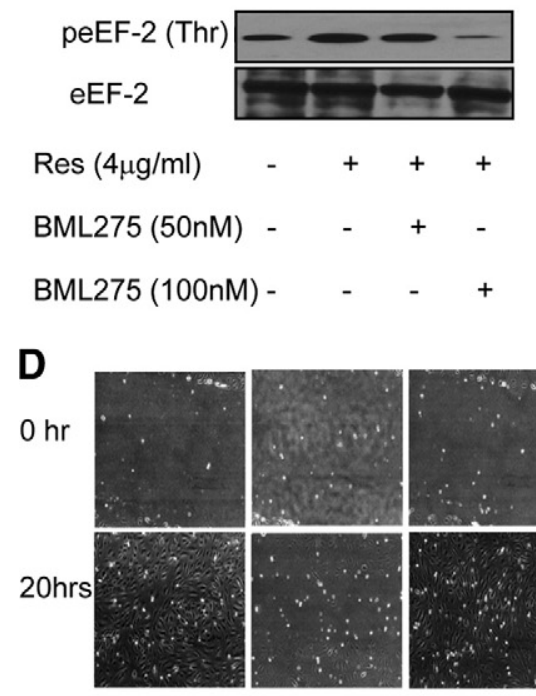

Medium Res $(4 \mu \mathrm{g} / \mathrm{ml})$
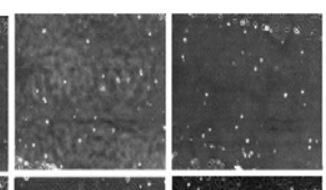

B

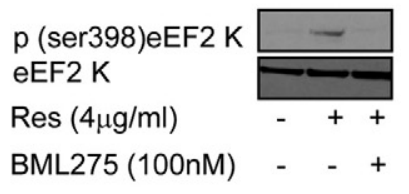

E
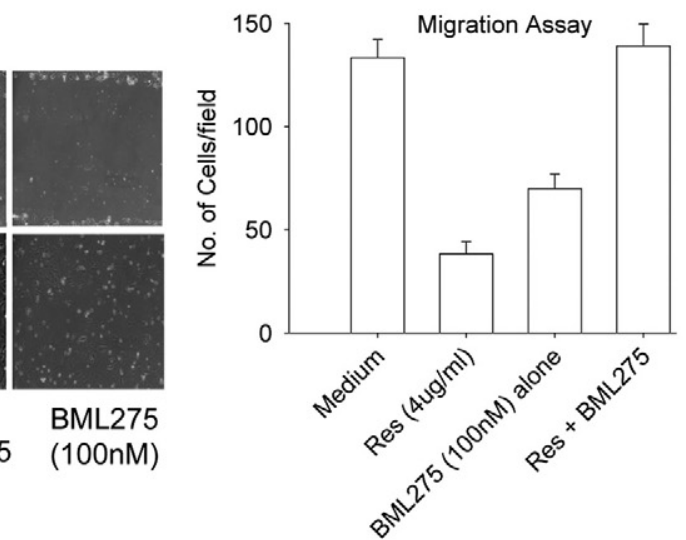

C

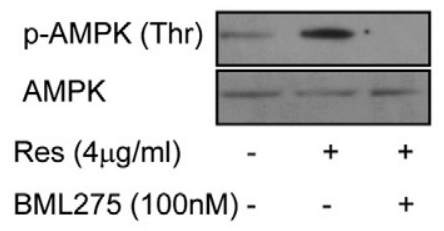

$\mathbf{F}$

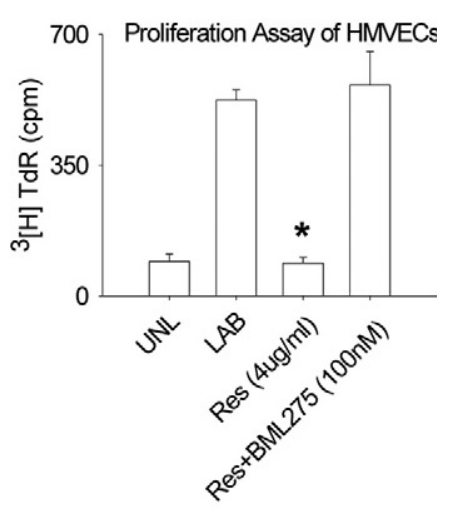

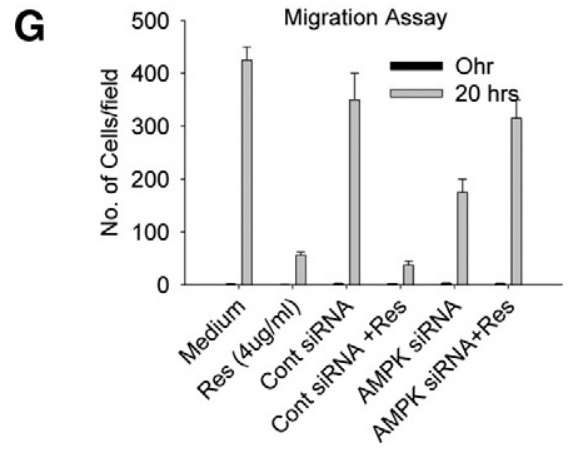

Figure 4. Resveratrol induced eEF2 and eEF2k phosphorylation are mediated by AMPK. A: HMVECs were pretreated with AMPK inhibitor BML275 $(50 \mathrm{nmol} / \mathrm{L}$ and $100 \mathrm{nmol} / \mathrm{L})$ for two hours and then treated with resveratrol $(4 \mu \mathrm{g} / \mathrm{ml})$ for 30 minutes. Cells were lysed, and lysates were evaluated for peEF2 (Thr) and total eEF2. B: eEF2k (ser398) phosphorylation and total eEF2k. C: HMVECs were pretreated with BML275 (100 $\mathrm{nmol} / \mathrm{L})$ for two hours and then treated with resveratrol $(4 \mu \mathrm{g} / \mathrm{ml})$ for 15 minutes. Cell lysates were evaluated for AMPK phosphorylation (Threonine). D: HMVECs were pretreated with BML275 (100 nmol/L) for two hours and then treated with resveratrol $(4 \mu \mathrm{g} / \mathrm{ml})$ for 20 hours. Cell migration was measured in the scratch assay. E: Cells were counted in four random fields in the scratched area after 20 hours and quantified. F: HMVECs were pretreated with BML275 $(100 \mathrm{nmol} / \mathrm{L})$ for two hours and then treated with resveratrol (4 $\mu \mathrm{g} / \mathrm{ml}$ ) for 20 hours. Cell proliferation was measured in the proliferation assay after addition of ${ }^{3} \mathrm{H}$ Thymidine. G: HMVECs were transfected with either control siRNA or AMPK siRNA. Cells were then treated with resveratrol for 20 hours, and cell migration was quantified in four random fields of scratched area. Values are averages \pm SE. ${ }^{*} P \leq 0.05$ by Student $t$ test. placed subcutaneously 7 days before laser injury. Treatment was continued for 7 days after laser injury, and eyes were harvested for analysis of CNV. Resveratrol-induced inhibition of CNV was neutralized by $\mathrm{NH} 125$ treatment, confirming that resveratrol-mediated effects on CNV are eEF2- and eEF2k-dependent (Figure 5D). Because $\mathrm{NH} 125$ is a pharmacological inhibitor of eEF2k function, we wanted to confirm these findings in eEF2 $k^{-1-}$ mice. In eEF2 $k^{-1-}$ mice, resveratrol failed to inhibit CNV while it showed robust inhibition of CNV in littermate controls (Figure 5E). We were interested in knowing whether the inhibitory effects of resveratrol extended to systemic angiogenesis outside the eye. We tested the role of resveratrol in extraocular angiogenesis in the subcutaneous matrigel plug assay. Mice were treated with i) vehicle control (25\% EtOH), ii) resveratrol (45 mg/kg), iii) NH125 (25 $\mathrm{mg} / \mathrm{kg}$ ), and iv) $\mathrm{NH} 125$ + resveratrol for 7 days using osmotic pumps (14-day pumps) before matrigel injection. We observed that resveratrol-treated matrigel plugs had significantly less $(P<0.05)$ hemoglobin than vehicletreated or $\mathrm{NH} 125$-treated matrigel plugs (Figure 5F). These results were further validated in eEF2 $k^{-1-}$ mice (Figure 5G). These data confirm that the effects of resveratrol on angiogenesis extend to multiple capillary beds, are mediated by eEF2 and eEF2k, and are independent of Sirt1.

\section{Discussion}

Resveratrol is a natural compound that has been of great interest because of its protective effects in aging and obesity and its ability to blunt the biochemical effects of senescence and high-fat Western diets. ${ }^{1-4}$ The effects of resveratrol on these diverse processes are thought to be mediated by sir2 or its mammalian homolog Sirt1. We have demonstrated that resveratrol can inhibit pathological angiogenesis by a novel Sirt1-independent pathway. The effects of resveratrol on angiogenesis extend to multiple capillary beds. In this article, we have shown that resveratrol inhibits injury-induced angiogenesis in the eye and subcutaneous angiogenesis seen in response to growth factor-enriched matrigel plugs. Although resveratrol has previously been shown to be pro- and antiangiogenic, it has not been shown to affect eEF2 activation. Resveratrol appears to do so by serine 398 phosphorylation and activation of eEF2k, a dedicated kinase that regulates eEF2 activity. ${ }^{30-34}$ Activated eEF2k in turn in- 
A

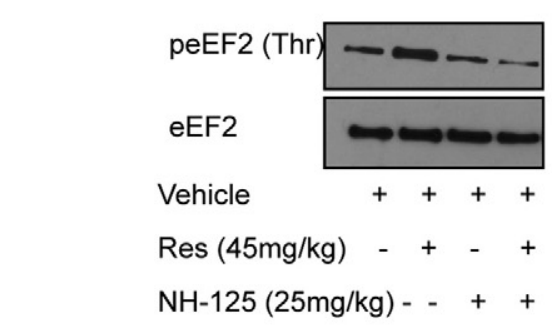

B

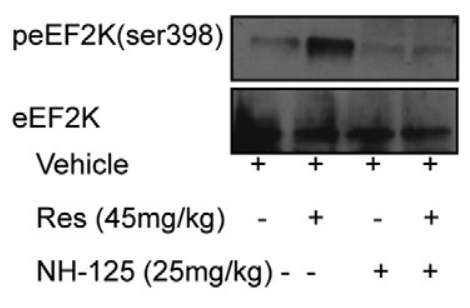

C

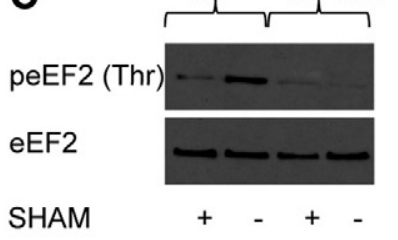

$\operatorname{Res}(45 \mathrm{mg} / \mathrm{kg})-+-+$

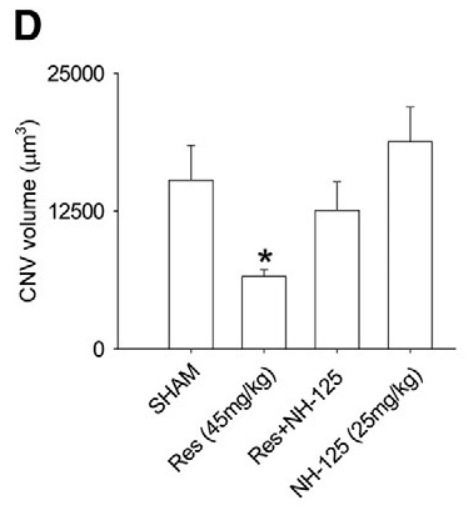

E

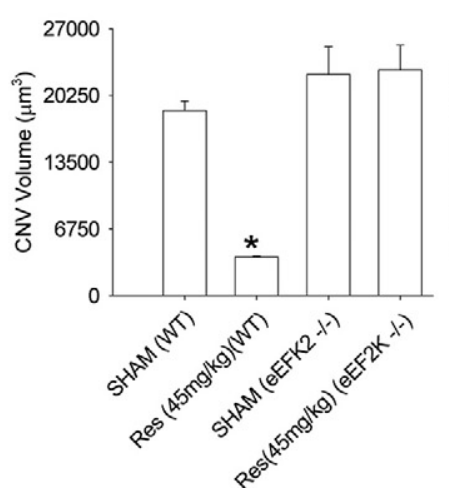

$\mathbf{F}$

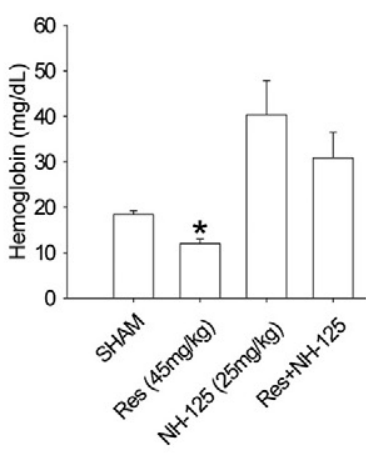

G

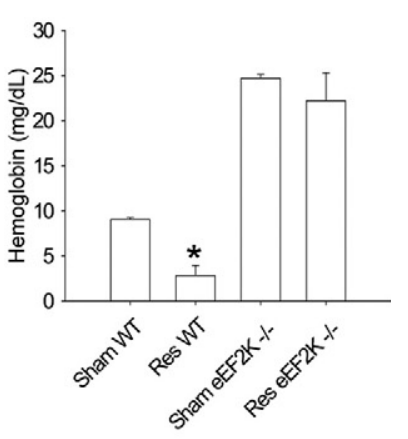

Figure 5. Neutralization or deficiency of eEF2k completely abolishes the effect of resveratrol on CNV and angiogenesis in matrigel plugs in vivo. A: C57BL6 mice were treated with i) vehicle, ii) resveratrol ( $45 \mathrm{mg} / \mathrm{kg})$, iii) NH125 (25 mg/kg), or iv) resveratrol + NH125 for seven days using osmotic sustained release pumps before laser injury. Eyes were harvested, and lysates were analyzed for eEF2 phosphorylation (Thr). B: Lysates were also analyzed for eEF2k phosphorylation (ser 398). C: $e E F 2 K^{-}$mice and wild-type littermate controls were treated with i) vehicle or ii) resveratrol ( $\left.45 \mathrm{mg} / \mathrm{kg}\right)$. Mice were lasered and eyes were collected after seven days. Eyes were then lysed and analyzed for eEF2 phosphorylation (Thr). D: C57BL6 mice ( $n \geq 5)$ were treated with resveratrol ( 45 mg/kg) and NH125 $(25 \mathrm{mg} / \mathrm{kg})$. Mice were lasered and treatment was continued for seven more days. CNV was quantified by confocal microscopy. E: $e E F 2 K{ }^{-1-}$ mice $(n \geq 5)$ and littermate controls $(n=5)$ were treated with vehicle or resveratrol $(45 \mathrm{mg} / \mathrm{kg})$ pumps and were lasered. CNV volumes were quantified seven days after laser. F: C57BL6 ( $n \geq 5$ ) were treated with i) vehicle, ii) resveratrol ( $45 \mathrm{mg} / \mathrm{kg})$, iii) NH125 ( $25 \mathrm{mg} / \mathrm{kg}$ ), or iv) resveratrol + NH125 for seven days before matrigel injection. Matrigel (200 $\mu \mathrm{l} / \mathrm{mouse})$ was injected subcutaneously, and treatment was continued for seven days. Mice were then killed and matrigel plugs were collected and evaluated for hemoglobin. G: $e E F 2 K^{-1}$ mice $(n \geq 5)$ and wild-type littermate controls were treated with vehicle or resveratrol ( $\left.45 \mathrm{mg} / \mathrm{kg}\right)$ for seven days. Mice were then injected subcutaneously with matrigel (200 $\mu \mathrm{l} / \mathrm{mouse})$. Matrigel plugs were collected and evaluated for hemoglobin after seven days. Results are averages \pm SE. ${ }^{*} P \leq 0.05$ by Student $t$ test.

duces threonine phosphorylation and inactivation of eEF2. Although eEF2k can be autophosphorylated at serine or threonine residues in the presence of calcium/ calmodulin in cell free systems, ${ }^{32,40}$ there is no evidence for in vivo eEF2k autophosphorylation in the literature. On the other hand, eEF2k can be directly phosphorylated by various kinases at multiple sites. Most of these kinases like cdc2 cyclin B, SAPK4 (p388), MAPKAP-K2/K3, S6K1, RSKs phosphorylate eEF2k at different serine residues leading to the inhibition of its activity. ${ }^{35,36,41,42}$ Unlike these kinases that inhibit eEF2k activity, AMPK can phosphorylate eEF2k on serine 398 leading to its activation. ${ }^{37}$ This is consistent with our results that AMPK mediates the activation of eEF2k that subsequently inhibits eEF2 activity. As shown above, pharmacological inhibition and RNA silencing of AMPK significantly reversed the effect of resveratrol on endothelial cells. In contrast, the regulation of eEF2 is relatively well characterized. It is phosphorylated at threonine 56 and threonine 58 residues mostly by eEF2k, but AMPK can also directly phosphorylate eEF2. ${ }^{43}$ This might explain some background phosphorylation seen in eEF2 $k^{-1-}$ mice. The eEF2 direct phosphorylation by AMPK does not appear to be relevant to our phenotype (i.e., pathological angiogenesis, as in eEF2 $k^{-1-}$ mice), as we observed complete reversal of the effects of resveratrol on ocular and extraocular angiogen- esis. Eukaryotic EF2 is a critical protein that mediates ribosomal transfer and protein translation, and mice deficient in eEF2 are not viable. Inactivation of this key molecule by resveratrol induces cell cycle arrest and inhibits the proliferation and migration of vascular endo-

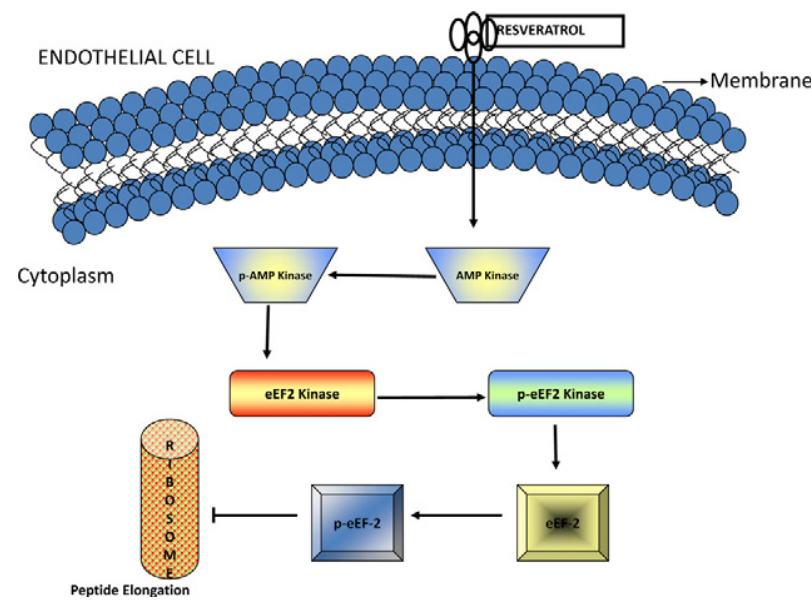

Figure 6. Schematic representation of resveratrol-mediated effects on endothelial cells. Resveratrol phosphorylates and activates eEF2 kinase via AMP kinase. Activation of eEF2 kinase leads to inactivation of eEF2. Inactivation of eEF2 inhibits vascular endothelial cell proliferation. 
thelial cells (HMVECs) in vitro. Endothelial cell proliferation and migration are necessary events during angiogenesis in vivo, and as such inhibition of eEF2 activity in mice either by pharmacological means or by gene deletion leads to a severely blunted neovascular response after injury in vivo.

The results in this study have unraveled a novel pathway by which the naturally occurring compound resveratrol affects vascular behavior (Figure 6). At a disease pathophysiology level, the findings of this study might have a significant impact on our understanding of angioproliferative diseases that are characterized by abnormal angiogenesis both within and outside the eye. Examples of ocular diseases with exuberant and abnormal angiogenesis include agerelated macular degeneration, diabetic retinopathy, and retinopathy of prematurity. These disorders encompass the leading causes of all blindness, and an understanding of the pathophysiology of abnormal angiogenesis in these conditions might facilitate the development of novel therapeutic approaches. Examples of systemic diseases that have abnormal angiogenesis at the center of their pathobiology include several cancers, atherosclerosis, and ischemic heart disease. These properties of resveratrol, including its ability to inhibit the migration and proliferation of endothelial cells in sprouting vasculature and to induce cell cycle arrest in these cells, could be potentially exploited to treat disorders highlighted above that have abnormal angiogenesis as a central feature of disease pathogenesis.

\section{References}

1. Baur JA, Pearson KJ, Price NL, Jamieson HA, Lerin C, Kalra A, Prabhu VV, Allard JS, Lopez-Lluch G, Lewis K, Pistell PJ, Poosala S, Becker KG, Boss O, Gwinn D, Wang M, Ramaswamy S, Fishbein KW, Spencer RG, Lakatta EG, Le Couteur D, Shaw RJ, Navas P, Puigserver P, Ingram DK, de Cabo R, Sinclair DA: Resveratrol improves health and survival of mice on a high-calorie diet. Nature 2006, 444:337-342

2. Baur JA, Sinclair DA: Therapeutic potential of resveratrol: the in vivo evidence. Nat Rev Drug Discov 2006, 5:493-506

3. Howitz KT, Bitterman KJ, Cohen HY, Lamming DW, Lavu S, Wood JG, Zipkin RE, Chung P, Kisielewski A, Zhang LL, Scherer B, Sinclair DA: Small molecule activators of sirtuins extend Saccharomyces cerevisiae lifespan. Nature 2003, 425:191-196

4. Marambaud P, Zhao H, Davies P: Resveratrol promotes clearance of Alzheimer's disease amyloid-beta peptides. J Biol Chem 2005, 280:37377-37382

5. Lekli I, Szabo G, Juhasz B, Das S, Das M, Varga E, Szendrei L, Gesztelyi R, Varadi J, Bak I, Das DK, Tosaki A: Protective mechanisms of resveratrol against ischemia-reperfusion-induced damage in hearts obtained from Zucker obese rats: the role of GLUT-4 and endothelin. Am J Physiol Heart Circ Physiol 2008, 294:H859-H866

6. Helge JW: Prolonged adaptation to fat-rich diet and training; effects on body fat stores and insulin resistance in man. Int $\mathrm{J}$ Obes Relat Metab Disord 2002, 26:1118-1124

7. Zhang J: Resveratrol inhibits insulin responses in a SirT1-independent pathway, Biochem J 2006, 397:519-527

8. Dali-Youcef N, Lagouge M, Froelich S, Koehl C, Schoonjans K, Auwerx $\mathrm{J}$ : Sirtuins: the 'magnificent seven', function, metabolism and longevity. Ann Med 2007, 39:335-345

9. Ates O, Cayli SR, Yucel N, Altinoz E, Kocak A, Durak MA, Turkoz Y, Yologlu S: Central nervous system protection by resveratrol in streptozotocin-induced diabetic rats. J Clin Neurosci 2007, 14: $256-260$
10. Kahn BB: Lilly lecture 1995. Glucose transport: pivotal step in insulin action. Diabetes 1996, 45:1644-1654

11. Mizutani K, Ikeda K, Yamori Y: Resveratrol inhibits AGEs-induced proliferation and collagen synthesis activity in vascular smooth muscle cells from stroke-prone spontaneously hypertensive rats. Biochem Biophys Res Commun 2000, 274:61-67

12. Garvin S, Ollinger K, Dabrosin C: Resveratrol induces apoptosis and inhibits angiogenesis in human breast cancer xenografts in vivo. Cancer Lett 2006, 231:113-122

13. Kaga S, Zhan L, Matsumoto M, Maulik N: Resveratrol enhances neovascularization in the infarcted rat myocardium through the induction of thioredoxin-1, heme oxygenase-1 and vascular endothelial growth factor. J Mol Cell Cardiol 2005, 39:813-822

14. Ryazanov AG: Elongation factor-2 kinase and its newly discovered relatives. FEBS Lett 2002, 514:26-29

15. Hsu TC, Chiang SY, Huang CY, Tsay GJ, Yang CW, Huang CN, Tzang BS: Beneficial effects of treatment with transglutaminase inhibitor cystamine on macrophage response in NZB/W F1 mice. Exp Biol Med (Maywood) 2007, 232:195-203

16. Liu YQ, Han J, Epstein PN, Long YS: Enhanced rat beta-cell proliferation in $60 \%$ pancreatectomized islets by increased glucose metabolic flux through pyruvate carboxylase pathway. Am J Physiol Endocrinol Metab 2005, 288:E471-E478

17. Zhou G, Myers R, Li Y, Chen Y, Shen X, Fenyk-Melody J, Wu M, Ventre J, Doebber T, Fujii N, Musi N, Hirshman MF, Goodyear LJ, Moller DE: Role of AMP-activated protein kinase in mechanism of metformin action. J Clin Invest 2001, 108:1167-1174

18. Apte RS, Barreiro RA, Duh E, Volpert O, Ferguson TA: Stimulation of neovascularization by the anti-angiogenic factor PEDF. Invest Ophthalmol Vis Sci 2004, 45:4491-4497

19. Kelly J, Ali Khan A, Yin J, Ferguson TA, Apte RS: Senescence regulates macrophage activation and angiogenic fate at sites of tissue injury in mice. J Clin Invest 2007, 117:3421-3426

20. Solomon JM, Pasupuleti R, Xu L, McDonagh T, Curtis R, DiStefano PS, Huber LJ: Inhibition of SIRT1 catalytic activity increases p53 acetylation but does not alter cell survival following DNA damage. Mol Cell Biol 2006, 26:28-38

21. Arora S, Yang JM, Kinzy TG, Utsumi R, Okamoto T, Kitayama T, Ortiz PA, Hait WN: Identification and characterization of an inhibitor of eukaryotic elongation factor 2 kinase against human cancer cell lines. Cancer Res 2003, 63:6894-6899

22. Liu $Y Q$, Jetton TL, Leahy JL: beta-Cell adaptation to insulin resistance. Increased pyruvate carboxylase and malate-pyruvate shuttle activity in islets of nondiabetic Zucker fatty rats. J Biol Chem 2002, 277:39163-39168

23. Liang CC, Park AY, Guan JL: In vitro scratch assay: a convenient and inexpensive method for analysis of cell migration in vitro. Nat Protoc 2007, 2:329-333

24. Smith JS, Brachmann CB, Celic I, Kenna MA, Muhammad S, Starai VJ, Avalos JL, Escalante-Semerena JC, Grubmeyer C, Wolberger C, Boeke JD: A phylogenetically conserved NAD+-dependent protein deacetylase activity in the Sir2 protein family. Proc Natl Acad Sci U S A 2000, 97:6658-6663

25. Passaniti A, Taylor RM, Pili R, Guo Y, Long PV, Haney JA, Pauly RR, Grant DS, Martin GR: A simple, quantitative method for assessing angiogenesis and antiangiogenic agents using reconstituted basement membrane, heparin, and fibroblast growth factor. Lab Invest 1992, 67:519-528

26. Choudhri TF, Hoh BL, Solomon RA, Connolly ES Jr, Pinsky DJ: Use of a spectrophotometric hemoglobin assay to objectively quantify intracerebral hemorrhage in mice. Stroke 1997, 28:2296-2302

27. Espinosa-Heidmann DG, Suner IJ, Hernandez EP, Monroy D, Csaky KG, Cousins SW: Macrophage depletion diminishes lesion size and severity in experimental choroidal neovascularization. Invest Ophthalmol Vis Sci 2003, 44:3586-3592

28. Brown DM, Kaiser PK, Michels M, Soubrane G, Heier JS, Kim RY, Sy JP, Schneider S: Ranibizumab versus verteporfin for neovascular age-related macular degeneration. N Engl J Med 2006, 355:14321444

29. Potente M, Ghaeni L, Baldessari D, Mostoslavsky R, Rossig L, Dequiedt F, Haendeler J, Mione M, Dejana E, Alt FW, Zeiher AM, Dimmeler S: SIRT1 controls endothelial angiogenic functions during vascular growth. Genes Dev 2007, 21:2644-2658

30. Greenberg CS, Birckbichler PJ, Rice RH: Transglutaminases: multi- 
functional cross-linking enzymes that stabilize tissues. FASEB J 1991, 5:3071-3077

31. Pineiro D, Gonzalez VM, Hernandez-Jimenez M, Salinas M, Martin ME: Translation regulation after taxol treatment in NIH3T3 cells involves the elongation factor (eEF)2. Exp Cell Res 2007, 313: 3694-3706

32. Ryazanov AG: Ca2+/calmodulin-dependent phosphorylation of elongation factor 2. FEBS Lett 1987, 214:331-334

33. Ryazanov AG, Davydova EK: Mechanism of elongation factor 2 (EF-2) inactivation upon phosphorylation. Phosphorylated EF-2 is unable to catalyze translocation, FEBS Lett 1989, 251:187-190

34. Ryazanov AG, Shestakova EA, Natapov PG: Phosphorylation of elongation factor 2 by EF-2 kinase affects rate of translation. Nature 1988, 334:170-173

35. Wang X, Li W, Williams M, Terada N, Alessi DR, Proud CG: Regulation of elongation factor 2 kinase by p90(RSK1) and p70 S6 kinase. EMBO J 2001, 20:4370-4379

36. Smith EM, Proud CG: cdc2-cyclin B regulates eEF2 kinase activity in a cell cycle- and amino acid-dependent manner. EMBO J 2008, 27:1005-1016

37. Horman S, Browne G, Krause U, Patel J, Vertommen D, Bertrand L, Lavoinne A, Hue L, Proud C, Rider M: Activation of AMP-activated protein kinase leads to the phosphorylation of elongation factor 2 and an inhibition of protein synthesis. Curr Biol 2002, 12:14191423

38. Diggle TA, Subkhankulova T, Lilley KS, Shikotra N, Willis AE, Redpath NT: Phosphorylation of elongation factor-2 kinase on serine 499 by cAMP-dependent protein kinase induces $\mathrm{Ca} 2+$ /calmodulin-independent activity, Biochem J 2001, 353:621-626

39. Dasgupta B, Milbrandt J: Resveratrol stimulates AMP kinase activity in neurons. Proc Natl Acad Sci U S A 2007, 104:7217-7222

40. Redpath NT, Proud CG: Purification and phosphorylation of elongation factor-2 kinase from rabbit reticulocytes. Eur J Biochem 1993, 212:511-520

41. Knebel A, Haydon CE, Morrice N, Cohen P: Stress-induced regulation of eukaryotic elongation factor 2 kinase by SB 203580-sensitive and -insensitive pathways. Biochem J 2002, 367:525-532

42. Knebel A, Morrice N, Cohen P: A novel method to identify protein kinase substrates: eEF2 kinase is phosphorylated and inhibited by SAPK4/p38delta. EMBO J 2001, 20:4360-4369

43. Hong-Brown LQ, Brown CR, Huber DS, Lang CH: Alcohol regulates eukaryotic elongation factor 2 phosphorylation via an AMP-activated protein kinase-dependent mechanism in C2C12 skeletal myocytes. J Biol Chem 2007, 282:3702-3712 